\title{
Semper Aliquid Novi \\ (n)

\author{
Reclaiming the Future of Book History \\ from an African Perspective
}

Peter D. McDonald

The study of books has a complex genealogy that can be traced back at least to the nineteenth century, especially if we bear in mind the long history of British bibliography. Yet it was only when an international group of historians, literary scholars, bibliographers, sociologists and librarians began to coordinate their various activities in the I960s and I970s that the "history of the book" emerged as a distinct scholarly enterprise, and it was only in the following decade that it started to see itself as a discipline in the making. The defining year was I982, which saw the publication of Robert Darnton's essay-cum-manifesto "What is the History of Books?" and the appearance of the first volume of the Histoire de l'édition française. These two events put the field on the map and set the terms of its development as a discipline over the next two decades.

As a series of national histories comparable to the inaugural French project started to appear in Britain, America, Holland, Ireland, Scotland, Australia, and elsewhere, scholars around the world began creating the infrastructure that would enable the new field to "win a place alongside fields like the history of science and the history of art in the canon of scholarly disciplines," as Darnton put it. ${ }^{\mathrm{I}}$ The Society for the History of Authorship, Reading and Publishing (SHARP), now the main professional forum for book historians, was founded in I99I (membership now just under 2,000); and the flagship journal Book History, which you are reading, was launched in I998, a major addition to the eighty-odd journals that currently welcome work in the field. At the same time, building on earlier developments, new centres of the book emerged from Cape Town to Edinburgh, Oxford to Princeton; while universities around the world set up new specialist courses, following the lead of the University of London's MA in the History of the Book, which was inaugurated in 1995 . The publication of Routledge's Book 
History Reader in $200 \mathrm{I}$ (with a $2^{\text {nd }}$ edition in 2006) signalled that the pioneering phase was over and that a new discipline of what the blurb for that volume called "book history studies" had indeed arrived. ${ }^{2}$

Over the past thirty years these initiatives have raised the field's profile and established its credentials as a discipline in its own right. They have also played a vital part in shaping the impact it has had on a wide range of more traditional disciplines within the humanities and social sciences. In the process of acquiring its own professional status, the history of the book has encouraged historians to see books themselves not just as indices but as agents of historical change in societies as diverse as France in the $1780 \mathrm{~s}$ and India in the I920s; it has fostered a greater awareness among literary scholars of the materiality of the book as a medium and of the institutions in which acts of writing and reading take place; it has led social scientists to analyse the publishing industry as an intricately structured, evolving world of its own, albeit one linked in complex ways to the larger forces at work in social, economic, and political history; it has even made inroads into the otherwise rarefied world of philosophy, where it has prompted reflection on the consequences for humanity of the emergence of a new multimedia age in which a paperless, and borderless, future is at least imaginable if not imminent; and it has led everyone with an interest in cultural history to reexamine the meaning and value of libraries as repositories of the book in all its many forms and of communications media as a key factor influencing cultural practices of all kinds.

As is the case with any new discipline, the emergence of "book history studies" was not quite as straightforward as this overview suggests. At one level, this was inevitable. Far from simply seeking a place in "the canon of scholarly disciplines," a new form of enquiry, if it is worth taking seriously, will always unsettle traditional ways of thinking and challenge previously clear, often vigorously defended disciplinary boundaries. This is especially true if its primary object-the book in this case-has long been declared the property of more established scholarly disciplines. At another level, however, the unease it sometimes caused was less predictable. To begin with there were the difficulties of the name itself. "Book History," as the founding editors of this journal remarked in their inaugural volume, "is the least unsatisfactory name for this scholarly frontier, which is certainly not limited to books—or to historians." Rather, its "field of play," they insisted, "is the entire history of written communication: the creation, dissemination, and uses of script and print in any medium, including books, newspapers, periodicals, manuscripts, and ephemera." ${ }^{3}$ Expansive as it was, this formu- 
lation cut two ways. On the one hand, it opened up the question of the relations between oral and written forms of communication, which have always remained inextricably entangled with each other. On the other hand, for a claim made in the late I990s, it oddly left digital modes out of the equation altogether. That the editors concluded their introduction with the "promise" that their journal would "change the way we read words on paper" only compounded this last problem. ${ }^{4}$ Given these methodological quandaries, it might be better to see the field as involving the study of communications across all linguistic media: oral, manuscript, print, and digital.

Yet the term "book" stuck for reasons that had much to do with the particular circumstances out of which the discipline emerged in the I980s and the methodological assumptions against which it was initially defined. For many early champions of the field, its distinctiveness lay primarily in the scrupulous attention it brought to bear on the material history of all media, which more established disciplines all but ignored. As the editors of Book History observed, "historians have always relied on documents to reconstruct the past, and perhaps for that reason they overlooked, until very recently, the history of documents themselves." 5 Among historians, Elizabeth Eisenstein's The Printing Press as an Agent of Change (1979) and Darnton's own The Business of Enlightenment: A Publishing History of the Encyclopédie (I979) did much to effect this shift in outlook. Arguing against "a purely semantic definition of the text" in a seminal essay of I992, the French book historian Roger Chartier similarly insisted that "readers, in fact, never confront, abstract idealized texts detached from any materiality." Rather, "they hold in their hands or perceive objects and forms whose structures and modalities govern their reading or hearing." ${ }^{6}$ Characteristically, in making this claim, Chartier was concerned not just to correct the quantitative methods of the "Annales School" of French book history, against which he defined his own more qualitative approach, but what he took to be the neo-Platonic conceptions of text associated with French theory and literary studies. A comparable anti-Platonic drive can be seen in D.F. McKenzie's arguments against traditional forms of bibliography in favour of a "sociology of texts."7 Bringing the documentary medium, which had previously been neglected in favour of its contents, to the fore was, in other words, integral to the new discipline's bid for scholarly recognition. Hence the appeal of the term "book," the most iconic document in the West, which, if used metonymically, could be said to stand for all media.

For all its strategic value, the early emphasis on the materiality of the book in this sense had a number of unhappy methodological consequences. 
For one thing, it fostered countless case studies, all of which relentlessly reiterated the basic materialist or new documentalist point, albeit across a wide range of periods and contexts. For another, the focus on transforming "the way we read words on paper" privileged questions of reception, often at the expense of the other stages in the communicative process. Both these dangers are very much on display in the PMLA's otherwise indispensable special issue on "The History of the Book and the Idea of Literature," which appeared in January $2006 .{ }^{8}$ Somewhat perversely, given the anti-Platonic ambitions driving the emergence of book history, this had the effect of turning the book or document into a kind of materialist fetish, which was, from a methodological point of view, almost as abstract as the orthodox literary critic's text. It was as if the book itself, rather than the relations and questions it opened up, became the object of study. This particular risk, it is worth recalling, had been anticipated, not least in Darnton's founding essay of I982. His "communications circuit," a model showing how all the agents involved in the creation, dissemination, and reception of books relate to each other, was intended precisely to preempt narrow specialisation. "Some holistic view of the book as a means of communication," Darnton argued, "seems necessary if book history is to avoid being fragmented into esoteric specializations cut off from each other by arcane techniques and mutual misunderstanding." 9 Having sketched the various points on his circuit, which ran in a loop from the author to the reader, via the publisher and bookseller, he added that "book history concerns each phase of this process and the process as a whole, in all its variations over space and time and in all its relations with other systems, economic, political, and cultural, in the surrounding environment." 10 The other key aspect of Darnton's model was its internationalism. Books, he insisted, "do not respect limits either linguistic or national": "they have often been written by authors who belonged to an international republic of letters, composed by printers who did not work in their native tongue, sold by booksellers who operated across national boundaries, and read in one language by readers who spoke another." ${ }_{\text {II }}$ Reaffirming these two aspects of Darnton's model-its holism and its internationalism-is, I shall argue, essential as we contemplate the future of the discipline today. To get a clearer sense of the stakes involved, however, and to approach these broader methodological concerns from the perspective of African studies specifically, I would like first to consider another less wellknown context in which an idea for a holistic and international study of the book arose independently of Darnton's. 
In I980 J.M. Coetzee, then a lecturer in English Literature at the University of Cape Town, offered a course entitled "The Book in Africa" as a specialist final-year undergraduate option on the university's new African literature programme. It was a novel undertaking that, as his prospectus made clear, confronted some of the limitations of literary studies at the time:

We will be exploring some of the determinants of literary production not often dealt with in literary studies: environmental pressures of all kinds on writers, the economics of publishing and distributing literary works, the nature of the readership of literary works, etc. Since much of the information required for this kind of study is not readily available, students are forewarned that the course will entail a certain amount of bibliographical ferreting and a certain amount of practical investigative research. ${ }^{\mathrm{I} 2}$

Though Coetzee conceived of the course after reading Eisenstein's The Printing Press as an Agent of Change, he had not been following the rise of book history as such. His extensive reading list included Richard D. Altick's The English Common Reader (1957), Robert Escarpit's The Book Revolution (I966), Q.D. Leavis's Fiction and the Reading Public (1932), John Sutherland's Fiction and the Fiction Industry (I978), as well as a number of Hans Zell's studies on books in Africa, all of which made important, though indirect, contributions to the new field, but he did not cite the work of the more self-consciously pioneering book historians of the I960s and I970s such as Chartier, Darnton, Lucien Febvre, Henri-Jean Martin, McKenzie, or, indeed, Eisenstein herself. ${ }^{{ }^{3}}$ Instead, he directed his students to the field via a series of questions he had concerning the predicament of African writers in the second half of the twentieth century. His reading list gave special prominence to essays by, among others, Chinua Achebe, Ali Mazrui, Es'kia Mphahlele, Ngugi Wa Thiong'o, Emmanuel Obiechina, and Wole Soyinka.

Looked at from the perspective of this generation of African writers, it was impossible, Coetzee suggested, to see the book itself merely as a neutral medium. Given the history of its advent during the era of European colonisation and its role as an agent for change in postcolonial Africa, it had to be seen as a culturally freighted artefact in its own right. Though this downplayed the influence of Islamic scribal culture, which more recent scholarship has shown spread into sub-Saharan Africa in the course of the thirteenth century, it none the less remains the case that the arrival of the book, 
and eventually the printing press, from Europe after the fifteenth century represented a decisive event for African cultures in which the performing and visual arts, music, and varieties of orature constituted the traditionally dominant expressive media. ${ }^{\text {I4 }}$ In Coetzee's view, the consequences of this were not just cultural or political. "If we accept (following Ong, McLuhan, Goody) that print changes modes of thought," he remarked in his preparatory notes for the course, "then printing can be seen as the agent whereby the world is modernized." Echoing McLuhan's arguments in Understanding Media: The Extensions of Man (I964), he added that "it is the print quality of the artefact, not its content (the medium rather than the message) that is of prime importance." Yet, to understand this, and so to grasp the full implications of taking the book as an object of study in itself, it was essential to attend not just to the history of its advent in Africa or to "mundane social factors in the study of the growth of the reading habit, e.g., availability of light, of seating space in trains, etc." It was necessary also to analyse "the class structure of so-called emergent African nations" and, above all, the place of the "intelligentsia" in that structure, since this particular social faction was the "prime modernizing agent" for whom newspapers, periodicals and books of all kinds were essential media. Coetzee's endorsement of this well-established transformative paradigm, which Robert Fraser rightly challenges in Book History through Postcolonial Eyes (2008), was characteristically cautious, but he was willing to let it define the larger ambitions of his course. ${ }^{15}$

This line of enquiry, which took the publishing industry as its starting point, raised a number of pressing questions for students of African literature. "As long as African writers remain bound into a supranational system of publication (in the broadest sense)," Coetzee commented in his notes, "the old splits in consciousness (which may or may not aid production) will persist: writing for a national audience versus writing for an international audience; writing to foster nationalist values versus writing to foster internationalist values (the values of the international intelligentsia); writing after African models versus writing after metropolitan models; writing by African standards versus writing by metropolitan standards." Making the book the initial point of departure not only opened up key methodological opportunities for Africanists, however. It raised equally compelling questions for literary students in general. As Coetzee remarked, the course presupposed that "the unit of historical meaning is not who writes what at what time, but that, at a certain time, someone should write X, someone should publish it, someone should bring it to the attention of readers, and someone should read it." The primary object was "the complete act of 
transmission." For literary students, or scholars for that matter, schooled in one or another tradition of "close reading," who considered the "words on the page" to be their chief concern, this entailed a radical shift in orientation. "From this point of view," Coetzee continued, "it is not the publishing industry in isolation that must be examined, and certainly not the activity of writing (or texts in isolation), but the total industry that involves the sponsorship of texts (in part by the creation of a climate, in part by educational processes), the dissemination of texts (publishing, distribution, selling and lending), and the criticism of texts."

For literary students of the early I980s, Coetzee's emphasis on the "total industry," and his effort to displace attention away from the "activity of writing," was as challengingly novel as it was demanding. In addition to acquiring some expertise in a wide range of disciplines, including literary criticism, sociology, cognitive psychology, media studies, cultural history, politics and economics, he expected his students to have a firm grounding in what would now be called "book history" and to develop an appreciation of its relevance to African studies and humanistic scholarship generally. Among other things, he encouraged students to investigate "the location of bookstores in the Cape Peninsula and the types of clientele they serve"; "the library services in the black residential areas of the Cape"; and the histories and editorial policies of a number of "South African literary magazines" of the I960s and I970s. In addition, he suggested they might consider which "works by black South African writers" the apartheid censors "tended to proscribe" and which ones they "let through"; the "origin and development of the Heinemann African Writers series"; and, given the emphasis on South and West African contexts, he suggested that students might "compare and contrast Onitsha market literature with the South African fotoroman [photo-novel] in terms of themes and readership." Given all the ferreting involved, not to mention the fact that the course tested the limits of literary studies at the time, it is perhaps unsurprising that it was not a success. Though the University of Cape Town's embattled African Literature programme continued, Coetzee's "Book in Africa” option attracted few takers and it was shelved after the first year.

\section{III}

Since the turn of the millennium a new generation of scholars has changed the fortunes of the field decisively, establishing book history as a vital part 
of research and teaching across all areas of African studies. ${ }^{16}$ By focusing on the transnational aspects of the trade, which remain as marked today as they did in the colonial era, despite the relative strength of the local industry in countries like South Africa, Ghana, and Nigeria, they have extended and elaborated the internationalist vision Coetzee shared with Darnton. Caroline Davis's Creating Postcolonial Literature: African Writers and British Publishers (2013), which examines Oxford University Press's Three Crowns Series, a key rival to Heinemann's African Writers' Series, is exemplary in this regard. Yet, as Isabel Hofmeyr demonstrates in Gandhi's Printing Press (20I3), not all these networks evolved along established colonial lines. Focusing on the Indian ocean as a trans- or perhaps even supranational space of cultural intersection, she shows that some also formed the basis of complex, highly labile anti-colonial solidarities. As much of this scholarship suggests, however, living up to Darnton's holistic ambitions, or encompassing Coetzee's "complete act of transmission," has proved more of a challenge. Corinne Sandwith's A World of Letters (2014), an engaging study of interventionist literary magazines and newspapers in mid-twentieth-century South Africa, provides a particularly clear instance of the difficulties. Like many literary scholars influenced by developments within book history, Sandwith gives the forgotten intermediaries of culture, including reviewers, editors, critics, and essayists, their rightful place in history as shapers of opinion and as guardians of the public sphere. But unlike many in the first phase of the discipline's emergence, she does not analyse the various periodicals she studies in detail exclusively as material objects or documents. She examines the way they created "a public space for independent cultural-political debate," and, even more crucially, embodied the priorities of particular reading communities "that articulated a distinctive set of aesthetic, interpretive and evaluative norms." ${ }^{17}$ The emphasis she places on the norm-creating capacity of these micro-communities of letters is vital, but, unavoidably, the particular weighting she gives them raises questions of method. What place do poets, novelists, dramatists, and other less easily identifiable literary practitioners have in this kind of analysis? Or, more pressingly, what standing might literature itself have in any world of letters conceived in these terms? In relegating writers and literary works to the margins, Sandwith was drawing not only on the methods of book history understood in a particular delimited way. On this issue, she owed as much to cultural studies, which, in its more militant versions, rejected the literary altogether in favour of other, seemingly less ideologically burdened, forms of expression like film and television. Among the traditional varieties of 
literariness cultural studies rejected, Sandwith invokes "the Leavisite ideal of artistic detachment and the privileged place of art." ${ }_{\text {I } 8}$ Yet, if we accept that literature has never been reducible to literariness, in one or another of its many doubtfully generalised definitions, then I would argue it is not only possible but essential to bring it back into the frame. After all, a properly desacralized literature, which is the only kind worth taking seriously, is a site in which all "aesthetic, interpretive and evaluative norms" and, indeed, normativity itself are put in question.

To illustrate what it might mean to live up to Darnton and Coetzee's holism by keeping literature in this sense in the frame, we can turn briefly to James Currey's recent insider account of the fluctuating fortunes of the Heinemann African Writers' Series (AWS) from its inception in I962 to the late I980s. Describing the selection of any new title for the series, Currey recalls that, while the "initial discussion" was always "literary," the decision to publish had also to reflect "practical and political realities," most notably relating to the "economics of the firm and the publishing industry at the time," which, for a series like AWS, had everything to do with changing educational policies and resources, rather than with the vagaries of commercial bookselling. ${ }^{19}$ Billed as a modern literary imprint fashioned "by Africans for Africa" and modelled on the success of Penguin in the UK, the low-cost paperback series in fact began as a highly successful exercise in rebranding by a colonial educational publisher created by editors in London, Ibadan, and Nairobi for, in the first instance, secondary schools and universities in Anglophone Africa. ${ }^{\circ}$ As Davis has shown, this was equally true of more modest contemporary projects like Oxford University Press's Three Crowns Series. ${ }^{21}$ Unlike the popular, often fictionalised educational pamphlets that were produced locally in Nigeria and sold directly to readers via market stalls in towns like Onitsha, the AWS initially flourished as an elite-sponsored, supranational collaboration between a British-based commercial publisher and selected postcolonial African states, or, more accurately, government education departments. Following the wider economic crises of the early I980s, however, Currey and his colleagues were obliged to shift their attention to the UK and the US where, coincidentally, the advent of a multicultural approach to education created new opportunities that ensured the ongoing survival of the series just as the African market began to shrink. Taking the "complete act of transmission" as the "unit of historical meaning," then, we need to acknowledge not just that Chinua Achebe, say, wrote Things Fall Apart in the mid-I950s, but that Heinemann published it as the inaugural AWS volume in 1962, that African educators prescribed 
it for schools and universities, that a generation of African students consequently studied it, and that, after the economic crises of the I980s, the book began a new life as part of a very different "communications circuit" outside Africa. We also need to acknowledge that every decision Currey took as a publisher, from the selection of titles to the details of format and presentation, was affected by his own understanding of how these disparate and shifting circuits worked as integrated systems.

Currey's account not only reinforces the kind of holistic approach Coetzee and Darnton encouraged, it also offers detailed evidence to support their internationalism and the recent transnational turn in African book history. He confirms that while many Anglophone African writers contributed, willingly or testily, to a post-colonial project of nation-building, they also depended on a "supranational system of publication," dating from the colonial era, that was either specifically pan-African or more broadly Commonwealth. Despite the political developments of the I960s, this legacy was perpetuated in the immediate post-colonial era under the Traditional Markets Agreement, which divided the Anglophone world into two protected trading zones, one British, the other American. When this informal agreement collapsed in the mid-I970s, resulting in a more fluid arrangement of "open" and "closed" markets, the mismatch between legally agreed rights territories and politically defined national boundaries became if anything more acute. As always, this has particular significance for works originally written in English. The mismatch is less pronounced when it comes to Africa's numerous smaller languages, many of which continue to be contained within, without necessarily being coextensive with, national borders. Just how complex English-language rights agreements became in the I980s can be seen in the early publishing history of Mtututzeli Matshoba's short-story collection Call Me Not a Man. Initially published in I979 by Ravan Press as a paperback in apartheid South Africa, where it was immediately banned, the collection appeared simultaneously in a limited hardback edition under a co-publishing arrangement with Rex Collings, a small London publisher who specialised in African books. Two years later Longman produced a new paperback edition as part of its Drumbeat Series, the main rival to AWS, reissuing it as an African Classic in I987. Though the initial Longman agreement stipulated that Three Continents Press, then one of the principal Africanist publishers in the US, had the first option on the remaining English-language rights, they did not take them up and no US edition was ever produced. Looked at from the perspective of Call Me Not a Man, then, the Anglophone world of the I980s was divided into four distinct territories: 
South Africa (Ravan); UK (Collings); UK, the Caribbean, and Africa north of the Limpopo (Longman); US and Canada (Three Continents). This, of course, covers the book rights for the English language only. Ravan also managed to sell translation rights for French, German, and Dutch editions; and, given the potential for any twentieth-century book to be translated not just across languages but across media, they sold the drama and film rights for the story "A Glimpse of Slavery" and rights for a taped edition for the blind.22 Today this list of subsidiary rights would in all likelihood include digital media as well, which, unconstrained by the limits of physical territory as they are, make national boundaries look even less relevant. Like much literary history, book history is only now finding the resources adequate to the historiographical challenges these technological and legal developments pose.

By focusing on the inner workings of the African Writers' Series, Currey also provides a way into understanding the complex interplay between publishers and writers, or, more to the point, the norm-creating capacity of an imprint or series and the literary works it frames, publishes, and brings to the attention of readers. This began with the use of the word "African" in the series title itself. Always eager to prevent the term from being racialised, Heinemann, especially under Currey's direction, intended it to describe the writers' geographical origins, but through the cumulative effect of the dayto-day editorial decisions it quickly acquired a literary significance as well. AWS titles were not just by writers from Africa, they were powerful exemplars of modern African writing, at least in the sense in which the publishers sought to fashion that category. Currey worried that Bessie Head's disturbing study of racism and madness, A Question of Power (1974), for example, was not "really African" but "more closely related to the mainstream of Anglo-American internal writing." ${ }_{23}$ Though he eventually took it on as something of an experiment for the African market, he turned down J.M. Coetzee's avant-garde debut Dusklands (I974), which was arguably even less “African” in Currey's sense. By contrast, Ayi Kwei Armah's first novel The Beautyful Ones Are Not Yet Born (1969), one of the most successful titles in the series, seemed ideally suited to the AWS project, a point Heinemann underscored through various presentational devices. The blurbs taken from British newspaper reviews drew attention to the novel's topical themes, describing it as "a story of an upright man resisting the temptations of easy bribes and easy satisfactions," and identifying it generically as "a clever and uncomfortable moral fable." ${ }^{24}$ In addition, the inside pages of a later reissue advertised The Novels of Ayi Kwei Armah (I980), a critical 
study by Robert Fraser, which was also published by Heinemann. As the advertisement noted, Armah emerges from this account not as a moralizing Leavisite aesthete but "as a committed artist attempting to clear the path of cultural reconstruction by means of a dynamic philosophy of history." 25 Fraser, as it happens, was also a key editorial advisor for the series. What Heinemann saw itself as doing in the I960s and I970s, then, was creating a space, within the territories defined by their rights agreements, for writing that was "African" in so far as it addressed urgent historical questions in a realistic way and was "committed" in Sartre's charged sense of that term to the postcolonial project of reconstruction.

To follow this analysis through we would of course need to give a similar account of all the other points in the circuit, since every agent has the opportunity to reframe the book in her or his own normative terms in the course of enabling its onward transmission. In the case of Armah's novel, for instance, we would need to consider not just which reviewers and critics read it and how they did so, but how African syllabus-designers saw it as fitting with their educational objectives at the time. Prescribing a book is, after all, no less a normative act, subject to a number of institutional conditions, than publishing or reviewing. To complete the circuit, at least in this first African version, we would also need to establish how African students themselves read it. Developing an analysis of this kind is critical for two reasons: first, it makes it possible to track, as Sandwith, Davis, and others have shown, the normative effects of production, dissemination, and sponsorship-the "total industry" - on the history of literature; and second, it allows us to return to the "activity of writing," which, following Darnton and Coetzee, remains in the picture, though no longer as the privileged focal point. This return is necessary, in part, because we need, as Darnton insisted, to understand "the nature of a literary career, and how it was pursued," and how writers "deal with publishers, printers, booksellers, reviewers, and one another." ${ }^{26}$ It is also, as Coetzee argued, because we need to recognise that these contextual factors do not simply form the background to any act of writing. Whether serving as a spur or a constraint, they constitute its institutional conditions of possibility and, consequently, become internalised as part of an inner drama of expression. "As long as African writers remain bound into a supranational system of publication," Coetzee noted, "the old splits in consciousness (which may or may not aid production) will persist." ${ }^{27}$

The strained relations between Armah and Heinemann show just how fraught these potentially creative self-divisions and normative tensions can be. Accepting the manuscript for The Beautyful Ones in 1967 was, accord- 
ing to Currey, "the beginning of by far and away the worst relationship we ever experienced with an author." ${ }_{28}^{8}$ Giving his side of the story a few years later, Armah recalled his struggle "to find an African publisher as opposed to a neo-colonial writers' coffle owned by Europeans but slyly misnamed 'African'." 29 This acerbic testimony, which is by no means unusual in the history of publishing, confirms the normative power of the publishing process and opens up a series of challenging questions about the role of publishers not just as "the merchants of culture," to use John B. Thompson's recent title phrase, but as its sponsors..$^{\circ}$ In my view, it also obliges us to go back to the text of The Beautyful Ones itself not to contemplate it in its splendid isolation, or to champion the "privileged place of art," but to reassess its relationship to the larger project of African writing to which Heinemann and various educational institutions in Africa and elsewhere were committed. The opening paragraph alone hints at the possibilities:

The light from the bus moved uncertainly down the road until finally the two vague circles caught some indistinct object on the side of the road where it curved out in front. The bus had come to a stop. Its confused rattle had given place to an endless spastic shudder, as if its pieces were held together by too much rust ever to fall completely apart. ${ }^{3 \mathrm{I}}$

The figural language, implied allegory, and, perhaps above all, the understated allusion to Achebe's founding AWS title Things Fall Apart, itself an allusion to W.B. Yeats's “The Second Coming," invites a reading that goes beyond the protocols of literary realism, opening up the possibility of seeing the novel not just as a supplement to the postcolonial project of cultural reconstruction, as Heinemann presented it, but as a self-consciously disruptive and knowingly literary intervention in a history of writing about Africa. Such a return to the text is needed not because the future of book history depends on its capacity to change how we read, or, indeed, on its historical alliance with literary studies, but because book historians who ignore the challenges some forms of writing pose to normativity itself risk looking like art historians who have abandoned any interest in pictures in order to concentrate on the history of frames, or historians of science who are more eager to study the sociology of laboratories than the meaning of scientific discoveries. In the process, they also risk missing one of the most significant opportunities book history has as an interdisciplinary field for contributing to, and ideally reshaping, the future of literary studies in and beyond Africa. 


\section{Notes}

I. Robert Darnton, The Kiss of Lamourette (London: Faber, I990), I07.

2. David Finkelstein and Alistair McCleery, eds., The Book History Reader (Abingdon: Routledge, 2006), back cover.

3. Ezra Greenspan and Jonathan Rose, eds., "An Introduction to Book History," Book History I (I998): ix-xi.

4. Greenspan and Rose, "An Introduction," xi.

5. Greeenspan and Rose, "An Introduction," ix.

6. Roger Chartier, "Labourers and Voyagers: From the Text to the Reader," Diacritics 22, no. 2 (I992): 50.

7. Donald F. McKenzie, Bibliography and the Sociology of Texts (Cambridge: Cambridge University Press, I999).

8. Seth Lerer and Leah Price, eds., "The History of the Book and the Idea of Literature," PMLA I2I, no. I (January 2006), 9-229.

9. Darnton, The Kiss of Lamourette, II I.

Io. Darnton, The Kiss of Lamourette, II I.

I I. Darnton, The Kiss of Lamourette, I 35 .

I2. J. M. Coetzee, "The Book in Africa," Seminar notes, National English Literary Museum (NELM) (Grahamstown, South Africa), Box I3: 2.I.I.

I3. H.M. Zell's studies include African Book World and Press: A Directory (London: Zell, 1980) and Publishing in Africa in the Seventies (Ile-Ife: University of Ife Press, I975).

I4. Shamil Jeppie and Souleymane B. Diagne, eds., The Meanings of Timbuktu (Cape Town: HSRC Press, 2008).

I 5. See Robert Fraser, Book History through Postcolonial Eyes (London: Routledge, 2008), especially $3-26$.

I6. Besides the titles mentioned in the main text, the key monographs now shaping the field include: Archie Dick, The Hidden History of South Africa's Book and Reading Cultures (Toronto: University of Toronto Press, 20I2); Anthea Garman, Antjie Krog and the PostApartheid Public Sphere: Speaking Poetry to Power (Pietermaritzburg: University of KwaZuluNatal Press, 20I5); Isabel Hofmeyr, The Portable Bunyan: A Transnational History of The Pilgrim's Progress (Princeton: Princeton University Press, 2004); David Johnson, Imagining the Cape Colony: History, Literature and the South African Nation (Edinburgh: Edinburgh University Press, 20I r); Stephanie Newell, Ghanaian Popular Fiction: "Thrilling Discoveries in Conjugal Life" and Other Tales (Oxford: James Currey, 2000), as well as Literary Culture in Colonial Ghana: How to Play the Game of Life (Manchester: Manchester University Press, 2002); and Andrew van der Vlies, South African Textual Cultures: White, Black and Read all over (Manchester: Manchester University Press, 2007). While Mcebisi Ndletyana's edited collection African Intellectuals in $19^{\text {th }}$ and $20^{\text {th }}$ Century South Africa (Cape Town: HSRC Press, 2008) is invaluable particularly in relation to the periodical press, Print, Text and Book Cultures in South Africa (Johannesburg: Wits University Press, 20I 2), edited by Van der Vlies, and The Book in Africa: Critical Debates (London: Palgrave Macmillan, 2015), edited by Caroline Davis and David Johnson, authoritatively map the field and feature important new work by emergent scholars, including Nourdin Bejjit, Ruth Bush, Claire Ducournau, Jack Hogan, Elizabeth le Roux, Lily Saint, Hedley Twidle, Margriet van der Waal, and Jarad Zimbler. One indication of the recognition the field has recently achieved within literary studies is the fact that I was asked to contribute an essay on "The Book in South Africa" to the new Cambridge History of South African Literature (20I2), edited by David Attwell and Derek Attridge. I am grateful to Cambridge University Press for allowing me use a revised version of the paragraphs relating to Coetzee's course on the "Book in Africa" here. 
I7. Corinne Sandwith, A World of Letters: Reading Communities and Cultural Debates in Early Apartheid South Africa (Pietermaritzburg: University of KwaZulu-Natal Press, 20I4): 48.

I8. Sandwith, A World of Letters, 74 .

I9. James Currey, Africa Writes Back (Oxford: James Currey, 2008), viii.

20. James Currey, "The African Writers Series at 30 ," Southern African Review of Books, (March-April I993): 4 .

2I. Caroline Davis, Creating Postcolonial Literature: African Writers and British Publishers (London: Palgrave Macmillan, 2013), 93-I92.

22. All these rights details are derived from the title file for Call Me Not a Man held at the Ravan Press Archives by Macmillan SA in Johannesburg.

23. Peter D. McDonald, The Literature Police: Apartheid Censorship and its Cultural Consequences (Oxford: Oxford University Press, 2009): I I I.

24. Ayi Kwei Armah, The Beautyful Ones Are Not Yet Born (London: Heinemann, I975), back cover.

25. Armah, The Beautyful Ones, I 84 .

26. Darnton, The Kiss of Lamourette, I25.

27. Coetzee, "The Book in Africa."

28. Currey, Africa Writes Back, 73 .

29. Currey, Africa Writes Back, 75.

30. See John B. Thompson, The Merchants of Culture (Cambridge: Polity, 20I0). The problematics of sponsorship, as played out in the context of literary publishing in apartheid South Africa, feature prominently in McDonald, The Literature Police, see especially 83-I 57 and $219-342$.

3 I. Armah, The Beautyful Ones Are Not Yet Born, I. 